University of St. Thomas, Minnesota

UST Research Online

Marketing Faculty Publications

Marketing

2011

An Exploration of Key Connections Within Sales-Marketing

Interface

Avinash Malshe

University of St Thomas, amalshe@stthomas.edu

Follow this and additional works at: https://ir.stthomas.edu/ocbmktgpub

Part of the Marketing Commons

This Article is brought to you for free and open access by the Marketing at UST Research Online. It has been accepted for inclusion in Marketing Faculty Publications by an authorized administrator of UST Research Online. For more information, please contact asle4660@stthomas.edu. 


\title{
An exploration of key connections within sales-marketing interface
}

\author{
Avinash Malshe \\ Opus College of Business, University of St Thomas, Minneapolis, Minnesota, USA
}

\begin{abstract}
Purpose - The paucity of empirical research on the sales-marketing interface necessitates a detailed exploration of linkages that can forge stronger connection between these two functions. This paper aims to explicate the boundary conditions that may affect the role played by structure, language, and process linkages in forging sales-marketing connections, and to identify additional linkages that may play an important role in this interface. Design/methodology/approach - A total of 47 sales and marketing professionals across different organizations in diverse industries were interviewed.

Findings - The research finds that certain boundary conditions (e.g. organizational hierarchy, time horizon) may influence how structure, language, and process linkages may operate in this interface. It also extends linkage repertoire by identifying two critical linkages: social and philosophical. Its managerial contribution lies in stressing the importance of: vertical and horizontal communication bridges; marketing's flexibility; interpersonal relationships; and the philosophical bond between the two functions, in forging stronger connections.

Originality/value - This is one of the few qualitative empirical investigations of the sales-marketing interface. It broadens one's understanding of sales-marketing linkages, adds to linkage repertoire, and extends the interface literature.
\end{abstract}

Keywords Sales, Marketing

Paper type Research paper

\section{Introduction}

An executive summary for managers and executive readers can be found at the end of this article.

Across a broad spectrum of practice, the teams who are exhibiting the most effective practice and the best results displayed clear elements of "linkage" (Oliva, 2006).

Marketing and sales functions, together, play a critical role in insuring that firms deliver the desired customer value (Guenzi and Troilo, 2007). Needless to say, an effective sales-marketing interface becomes an important determinant of how well the firm creates, delivers, and communicates its value proposition. Recently, scholars (Biemans et al., 2009; Cespedes, 1993, 1996; Dewsnap and Jobber, 2000, 2002; Kotler et al., 2006; Malshe 2009a, b; Malshe and Sohi, 2009a, b; Rouziès et al., 2005) have started paying attention to this important interface. Interestingly, the majority of extant research suggests that marketing and sales functions do not get along owing to a variety of reasons such as different goals (Strahle et al., 1996), different perspectives of the world (Cespedes, 1996), physical separation and poor communication (Lorge, 1999), and poor coordination (Colletti and Chonko, 1997). Dewsnap and Jobber (2000), who note that conflict, non-cooperation, and mutually negative stereotyping characterize this relationship,

The current issue and full text archive of this journal is available at www.emeraldinsight.com/0885-8624.htm

Journal of Business \& Industrial Marketing 26/1 (2011) 45-57

(c) Emerald Group Publishing Limited [ISSN 0885-8624] [DOI 10.1108/08858621111097201] capture the "not so friendly" connection between the two functions.

Barring a few notable exceptions, extant research on salesmarketing interface is largely conceptual (Rouziès et al., 2005). Further, there are scattered references in the literature with respect to achieving greater integration (Rouziès et al., 2005), enhancing collaboration (LeMeunier-FitzHugh and Piercy, 2007), and improving inter-functional communication (Lorge, 1999) and cooperation (Homburg and Jensen, 2007) so that the connections between sales and marketing may be strengthened. While scholars have pointed to the acrimonious nature of this interface, as we highlight in our literature review, they have also suggested different courses of actions that marketing and sales departments might pursue to insure that the connections between them are improved. A close scrutiny of the literature in this area suggests that most empirical and conceptual studies on sales-marketing interface are descriptive and have developed models that embody language, structure, and process artifacts as dimensions of marketing-sales linkages. The body of knowledge on this interface will benefit if one explored the dynamic factors that may affect the role played by these already-known linkage dimensions in forging stronger connections, and investigated whether any additional linkages may exist between these two functions that may strengthen the sales-marketing connection.

Using interview data collected from 47 sales and marketing professionals, this paper builds on our extant knowledge to answer the following two research questions:

Received: January 2008

Revised: June 2008

February 2009

Accepted: July 2009 
1 Are there (yet) unexplored contextual conditions that may affect how the frequently-noted linkage dimensions (language, process, and structure) may forge strong connections between sales and marketing?

2 Are there additional linkages that the sales and marketing functions may focus on to strengthen the connection between them?

Theoretically, this paper extends the business marketing literature by explicating the boundary conditions that may affect how well the language, process, and structure elements may forge stronger linkages within the sales-marketing interface context. Its second contribution lies in identifying two new linkages - i.e. social and philosophical linkages thereby expanding the linkage repertoire. Its managerial contribution lies in stressing the importance of:

- vertical and horizontal communication bridges;

- marketing's flexibility;

- interpersonal relationships; and

- philosophical bond between the two functions in forging stronger connections.

I begin by reviewing the relevant literature. Next, I detail the study methodology. That is followed by discussion of the study findings and offering of propositions. The paper ends with highlighting study contributions, limitations, future research directions, and managerial implications.

\section{Literature review}

Marketing's interface with R\&D (e.g. Griffin and Hauser, 1996; Leenders and Wierenga, 2002; Moenaert and Souder, 1990), finance (Lim and Reid, 1992), manufacturing and production (Crittenden et al., 1993; Song et al., 1997), engineering (Weinrauch and Anderson, 1982), product development (Sherman et al., 2000), quality (Morgan and Piercy, 1998), and human resources (Chimhanzi, 2004) has been documented in the literature. In spite of its strategic importance, scholars did not pay much attention to the salesmarketing interface in the past. It is only very recently that the literature on this interface has begun to expand. Acknowledging the acrimonious nature of this interface, studies in this area have focused on a range of issues such as inter-functional relationships, cooperation, integration, alignment, coordination, and collaboration. A close scrutiny of this literature suggests that scholars have focused on elements such as organizational structure, communication processes and other operating characteristics, systems, goal and reward alignment, and leadership as building blocks to understand how sales and marketing departments may forge stronger connections. Table I highlights important studies and key scholarly insights about how sales and marketing departments may work toward strengthening interdepartmental connections.

It is not surprising that when sales and marketing departments are able to forge stronger connections, firms benefit. Relatedly, scholars have noted positive outcomes such as greater customer value (Guenzi and Troilo, 2006), overall business performance (Dewsnap and Jobber, 2002; Rouziès et al., 2005), enhanced departmental and product management performance (Kahn and Mentzer, 1996), and enhanced learning capabilities (Guenzi and Troilo, 2006).
Literature on the sales-marketing interface indicates that sales' and marketing's attempts to forge strong connections may meet obstacles (Lorge, 1999; Webster and Montgomery, 1997) owing to inter-functional conflicts, differences in goal orientation, tension regarding standardization and adaptation, (dis)connectedness from market conditions, turf and interpretive barriers, cultural differences, or differences in thought worlds, among other reasons. Specifically, Kotler et al. (2006) attribute inter-functional conflict to misalignment in goals and work processes. Dewsnap and Jobber (2000) indicate that goal conflict can be a cause of inter-group differentiation that may push the functions apart from one another. This may also be related to turf barriers (Hutt, 1995), which may compel each function to defend its control and power. Research has shown that such inter-group differentiation and turf barriers can adversely affect marketing-sales relationships. Scholars warn that firms should be aware not only of the functional-level conflicts but also the individual-level conflict between sales and marketing personnel. Firms must work on organizational (e.g. merging sales and marketing units) and individual levels (e.g. decreasing psychological distances between marketing and sales personnel) in order to reduce such conflict (Dawes and Massey, 2005).

It is plausible that these two functions may not always conflict openly with one another. However, many subtle differences between the two may work against forging stronger connections. Lack of alignment over objectives (Strahle et al., 1996) or lack of clear role definition (Kotler et al., 2006) may cause subtle acrimony. Firms may also encounter challenges such as cultural mismatch between sales and marketing (Beverland et al., 2006). Cultural divide may also enhance thought world and competence differences between the two functions (Homburg and Jensen, 2007). When these two functions do not get along well, it may affect many of the strategic outcomes as noted earlier.

In summary, while extant research provides the foundational blocks to understand the critical components needed for this interface to function optimally, this body of work will benefit if one explored the contextual factors that may affect the role played by the frequently noted linkage dimensions (language, process, and structure) in forging strong connections between sales and marketing, and also investigated whether there are additional linkages that the sales and marketing functions may focus on to strengthen the connections between the two. This paper addresses these two issues.

Next, I discuss study methodology.

\section{Method}

I conducted a multi-firm study using a grounded theory approach (Glaser and Strauss, 1967; Strauss and Corbin, 1998). Given that the majority of studies in this area are quantitative in nature, the use of a qualitative approach in studying this phenomenon adds value for the following three reasons. First, as Strauss and Corbin (1998) argue, both qualitative and quantitative forms of research have roles to play in theorizing (p. 34). Since the extant sales-marketing interface theory is at a nascent stage, the use of qualitative approach is helpful in identifying the yet unexplored boundary conditions of the extant theory and further our 
Table I Strengthening sales-marketing connections: key scholarly insights

\begin{tabular}{|c|c|c|}
\hline $\begin{array}{l}\text { Author(s)/whether the study is } \\
\text { empirical or conceptual }\end{array}$ & $\begin{array}{l}\text { Central focus/key construct(s) of the } \\
\text { study }\end{array}$ & $\begin{array}{l}\text { How the connections between sales and marketing may be } \\
\text { strengthened/what affects the connections between sales } \\
\text { and marketing }\end{array}$ \\
\hline $\begin{array}{l}\text { Beverland et al. (2006) } \\
\text { Empirical }\end{array}$ & $\begin{array}{l}\text { Cultural frames that drive sales and } \\
\text { marketing apart }\end{array}$ & $\begin{array}{l}\text { Removing implied status barriers } \\
\text { Providing salesforce with a strategic voice } \\
\text { Enhancing informal communication }\end{array}$ \\
\hline $\begin{array}{l}\text { Cespedes (1993) } \\
\text { Conceptual }\end{array}$ & Coordination between marketing and sales & $\begin{array}{l}\text { Creating liaison units that link } \mathrm{HQ} \text { with salesforce, multifunctional } \\
\text { account teams, career paths and training programs that expose } \\
\text { marketing personnel to sales activities (and vice versa) }\end{array}$ \\
\hline $\begin{array}{l}\text { Cespedes (1996) } \\
\text { Conceptual }\end{array}$ & $\begin{array}{l}\text { Activity synchronization between } \\
\text { marketing and sales }\end{array}$ & $\begin{array}{l}\text { Coordinating product, sales, and service management staff } \\
\text { activities } \\
\text { Enhancing cross-functional cooperation and information systems } \\
\text { Establishing lines of primary and joint authority }\end{array}$ \\
\hline $\begin{array}{l}\text { Dewsnap and Jobber (2000) } \\
\text { Conceptual }\end{array}$ & Inter-group integration & $\begin{array}{l}\text { Enhancing decentralization, participation, physical proximity, } \\
\text { engaging multiple groups } \\
\text { Initiating actions by senior management such as values integration } \\
\text { Providing opportunities, joint rewards }\end{array}$ \\
\hline $\begin{array}{l}\text { Dewsnap and Jobber (2002) } \\
\text { Conceptual }\end{array}$ & Inter-group differentiation & Reducing goal conflict and strength of in-group identity \\
\hline $\begin{array}{l}\text { Guenzi and Troilo (2006) } \\
\text { Empirical }\end{array}$ & Integration & $\begin{array}{l}\text { Enhancing communication and collaboration } \\
\text { Creating a positive climate } \\
\text { Enhancing trust, motivation, commitment }\end{array}$ \\
\hline $\begin{array}{l}\text { Homburg et al. (2008) } \\
\text { Empirical }\end{array}$ & Marketing and sales configurations & $\begin{array}{l}\text { Encouraging sharing of key information } \\
\text { Building structural linkages with sales functions through joint } \\
\text { planning and team work }\end{array}$ \\
\hline $\begin{array}{l}\text { Kahn and Mentzer (1996) } \\
\text { Empirical }\end{array}$ & Integration & Enhancing cross-functional interaction and collaboration \\
\hline $\begin{array}{l}\text { Kotler et al. (2006) } \\
\text { Conceptual }\end{array}$ & Integration & $\begin{array}{l}\text { Encouraging joint sales-marketing activities } \\
\text { Integrating systems, processes, and structures }\end{array}$ \\
\hline $\begin{array}{l}\text { LeMeunier-FitzHugh and Piercy (2007) } \\
\text { Empirical }\end{array}$ & Collaboration & $\begin{array}{l}\text { Senior management attitude } \\
\text { Reducing interdepartmental conflict } \\
\text { Improving communication } \\
\text { Instituting market intelligence systems and organizational learning } \\
\text { practices }\end{array}$ \\
\hline $\begin{array}{l}\text { Maltz (1996) } \\
\text { Conceptual }\end{array}$ & Cooperation/integration & $\begin{array}{l}\text { Creating cross-functional training and teams } \\
\text { Maintaining spatial proximity }\end{array}$ \\
\hline $\begin{array}{l}\text { Matthyssens and Johnston (2006) } \\
\text { Empirical }\end{array}$ & Coordination/integration & $\begin{array}{l}\text { Operating product management as a coordination mechanism } \\
\text { between sales and marketing } \\
\text { Creating customer-centric organizational structure } \\
\text { Maintaining timely and high quality communication } \\
\text { Appreciating the role of the other function }\end{array}$ \\
\hline $\begin{array}{l}\text { Oliva (2006) } \\
\text { Conceptual }\end{array}$ & Connections between sales and marketing & $\begin{array}{l}\text { Creating common definitions of key terms and nature of their } \\
\text { practice } \\
\text { Instituting approaches that favor "mixing" sales and marketing } \\
\text { Clearly defining marketing and sales role in demand generation }\end{array}$ \\
\hline Piercy (2006) & Strategic sales organization & Involving sales organization in strategy formulation \\
\hline Conceptual & & $\begin{array}{l}\text { Working across traditional organizational boundaries to meet } \\
\text { customer requirements } \\
\text { Involving sales organization in strategy formulation }\end{array}$ \\
\hline $\begin{array}{l}\text { Rouziès et al. (2005) } \\
\text { Conceptual }\end{array}$ & Integration & $\begin{array}{l}\text { Emphasizing decentralization, cross-functional teams, integrators, } \\
\text { communication, and job rotation } \\
\text { Promoting integrated goals/norms for information sharing } \\
\text { Reducing relative functional identity }\end{array}$ \\
\hline $\begin{array}{l}\text { Dawes and Massey (2006) } \\
\text { Empirical }\end{array}$ & Marketing-sales relationship & Enhancing interpersonal trust and interdependence \\
\hline
\end{tabular}


understanding of this phenomenon. Second, the use of qualitative methodology adds value in that it allows me to triangulate my findings with the extant knowledge in this area, thereby enabling me to build upon the foundations of the extant theory (Deshpandé, 1983). Third, the use of qualitative methodology enables me to study the interaction between these two functions in vivo (Gummesson, 2003), thus allowing for the emergence of new ideas that help expand sales marketing linkage repertoire. I further wish to note that this methodological approach is consistent with research in marketing (e.g. Kohli and Jaworski, 1990; Tuli et al., 2007) and business markets (Beverland et al., 2006; Matthyssens and Vandenbempt, 2003), and responds to the call by scholars (Dewsnap and Jobber, 2002; Rouziès et al., 2005) for a rigorous empirical investigation of the sales-marketing interface.

To accumulate wide range of experiences, I collected data through in-depth interviews with 25 sales and 22 marketing professionals in the USA (47 overall). The informants represented all levels within the marketing and sales functions (e.g. salesperson to national sales manager in sales organization; junior marketing executive to $\mathrm{CMO}$ in marketing organization). Further, they represented businessto-business firms in the pharmaceutical, telecom, IT, industrial products, healthcare, and engineering industries. Informant companies were comparable in size, and each firm had a distinct marketing and sales function.

The theoretical sampling technique is based on the concept of "making comparisons", which aims to go to places, people, or events that will maximize the discovery of variations among concepts to densify categories in terms of their dimensions (Strauss and Corbin, 1998, p. 201). Since the focus of the study was on expanding the linkage repertoire, I used theoretical sampling to recruit informants from two kinds of firms:

1 those that had constructive linkages between sales and marketing (26 informants); and

2 those that did not (21 informants).

I used two criteria to categorize firms as having (non) constructive sales-marketing linkages. First, prior to starting each interview, I asked my informant to share with me what he/she thought about the sales-marketing relationships within his/her firm. Their assessment of this relationship helped me gauge whether the two departments shared constructive linkages in their respective firms. Further, the experiences they shared gave me an additional indication regarding the nature of linkages between sales and marketing. I must note here that I confirmed my interpretation and categorization of firms with my informants during member checks.

I recruited informants using word of mouth and personal contacts (Tuli et al., 2007). Of the 54 sales-marketing professionals I contacted, seven declined the interview request for confidentiality reasons. My final sample size was 47. I insured anonymity to my informants. Each informant had been in his/her current job for at least three years; hence, he/she was conversant with the research topic. I informed them that the interviews pertained to understanding the interaction between sales and marketing functions in business markets. The interviews were discovery-oriented (Deshpandé, 1983), lasting about an hour or more. The shortest interview was about 50 minutes and the longest was 75 minutes. I conducted the interviews at a place and time convenient to informants. Of the 47 interviews, 39 were conducted in person and eight over phone. I began interviews in an exploratory manner so that I could focus on each individual's phenomenological interpretations (Glaser and Strauss, 1967). The questions related to the sales-marketing dynamic, connections between two functions, what helped maintain healthy connections, and challenges involved therein. The sales-marketing interface was the unit of analysis. While sticking to the interview protocol, I allowed informants to guide the flow and content of discussion and maintained objectivity to reduce interviewer-induced bias (McCracken, 1988). During the interviews, I made efforts to clarify ambiguities. This provided informants an opportunity to correct anything I might have misunderstood or to elaborate on certain aspects.

I taped all interviews and transcribed them verbatim. The 47 informant interviews represented more than 49 hours of audio recording. I managed the interview notes using QSR International's NVivo software. Following qualitative inquiry practices, I coded the data iteratively, seeking to find common themes. The themes were constantly refined based on subsequent interview data. At the beginning, open coding helped identify important concepts and their properties (Strauss and Corbin, 1998). Subsequently, axial coding helped relate various dimensions and facets emerging from the data to central constructs. To give the reader a sense of the coding process, in the Appendix I have shown examples of in vivo codes, first-order categories, and second-order themes. I stopped interviews upon reaching theoretical saturation (Strauss and Corbin, 1998). Throughout the analysis, I looked for the diversity of viewpoints and tried to capture the richness of data by not forcing emergent patterns into preconceived categories (Gummesson, 2003; Weick, 2007). I used two additional coders to vet my interpretation of the data. In addition, at the end of the study, I verified interpretations and the accuracy of my findings using member checks (Lincoln and Guba, 1985).

\section{Findings}

Extant theories of the sales-marketing interface ground the findings of this study. As I highlighted in Table I, extant research identifies the key role played by structure, communication (language), and process elements in bringing sales and marketing functions closer. Similarly, there is evidence in the sales-marketing interface, as well as in other streams of literature (Griffin and Hauser, 1996; Hutt, 1995; Kahn and Mentzer, 1996; Kohli and Jaworski, 1990; Lucas and Bush, 1988; Tjosvold, 1988) regarding the importance of the social and philosophical connections between departments. The findings of this study unify these diverse perspectives, highlight the key role played by important organizational-level variables in affecting an important interface dynamic, and expand the linkage repertoire by identifying social and philosophical linkages that these two functions must work on (see Figure 1). I discuss each of the elements below.

\section{Language}

Extant research highlights how inter-functional communication strengthens sales-marketing linkages (Guenzi and Troilo, 2006; Matthyssens and Johnston, 2006; Rouziès et al., 2005). 
Figure 1 Integrative framework

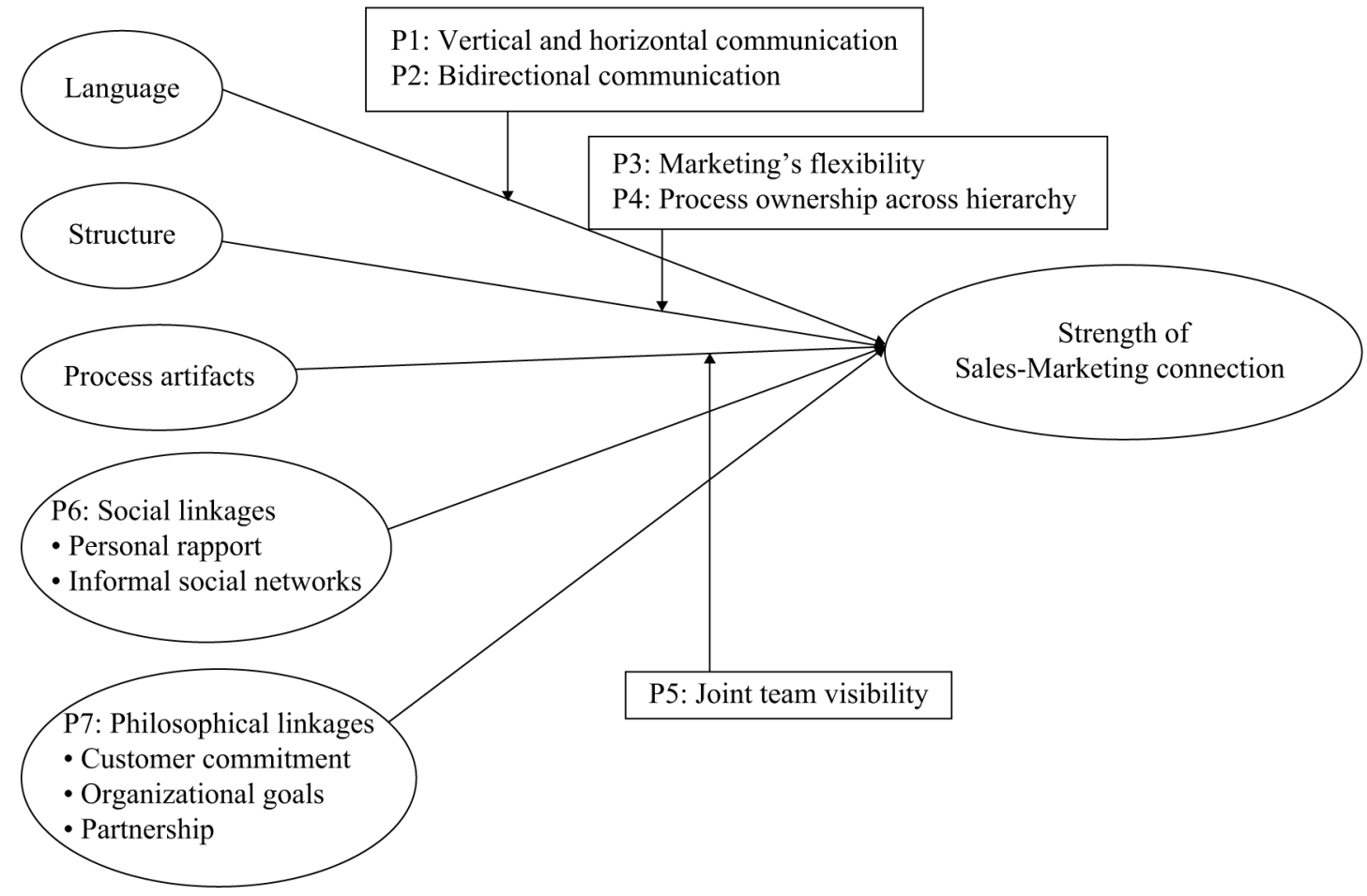

Specifically, Oliva (2006) states that the marketing-sales interface will be stronger if the two functions achieve alignment on definitions of key terms such as what "value" or "a lead" mean, and clarity on what the other function's activities are. Our data suggest that two boundary conditions affect whether achieving such alignment and clarity can benefit firms.

Organizational hierarchy is the first boundary condition. Individuals at different levels within the marketing and sales organizations have different roles, responsibilities, and day-today tasks; for example, people at the bottom of the pyramid may focus on selling/marketing products to specific customer groups, whereas sales and marketing vice presidents (VPs) may focus on strategic issues. Hence, before rolling out a strategy, even if the VPs agree upon definitions of firm's value proposition or what constitutes a lead, it is plausible that in the field, the lower-level executives will hold different notions compared to their superiors, or their sales (marketing) counterparts, about what "value" or "a lead mean". To address this challenge arising from the organizational hierarchy, in addition to agreeing upon key terms, sales and marketing departments need to do the following two things to strengthen their connection.

First, they must institute effective vertical communication mechanisms within each functional hierarchy to prevent information loss so that people at different levels understand the meanings of the core terms and how it may be contextually adapted. Jake laments below how a lack of effective communication channels poses a challenge in his firm:

Unfortunately, what we observe is by the time our communication goes out to the field, it is diluted. Therefore, the biggest concern that we have right now is how to communicate precisely the information about new target markets and new program features with each level within the sales force without losing its essence. We want them to understand the core concepts so that they can adapt ... but right now, those core concepts also get diluted (Jake, IT, VP Marketing).

Ray's comment below speaks to the notion of how his firm insures that everyone across the sales and marketing hierarchy possesses a uniform understanding of key terms. As such, it brings out the importance of constant communication within the marketing and sales hierarchy:

Execution happens on the field and hence it is crucial for our field personnel and their marketing support folks to have a clear understanding of our value proposition. We take this seriously. Our top executives are constantly in touch with their subordinates and the field personnel to insure that their understanding of our value proposition is as close as possible, to what the strategy document outlines. We do not want the meanings to get lost as the information flows from top to bottom. We strongly guard against it (Ray, Regional Marketing Manager, Healthcare).

Second, firms must also build communication bridges across various levels between the two functions so that sales and marketing professionals at the middle and the bottom of the rung can collectively decide how to interpret important terms in the context of field realities:

I would say, in this company, representatives from both functions need to work together to achieve specific business objectives and tasks. That has to be at the most senior level, where VP of Sales or VP of Marketing together define objectives, strategies, and customer benefits. Simultaneously, it should also be happening at my level, where the product manager and I are maybe figuring out together the objectives for my region or how to convert a particular account or address a particular customer concern (Serena, Telecom, Sales Representative)

The second boundary condition that affects whether agreement on key terms leads to stronger integration is the long-term nature of strategy creation and execution activities in business markets. Our informants noted that in many instances, it takes more than one quarter to execute strategies 
in business markets. Therefore, it is plausible that while rolling out strategies, even if the two groups (across all levels) agree on the meaning of key terms and the role each function will play in strategy implementation; as the strategy implementation unfolds, differences about how to define and communicate the final "value", or what the customers are actually looking for, can arise between sales and marketing. This is likely to force marketing and sales personnel to collectively rethink issues such as value definition, communication, and delivery. Further, should the strategies not work out as planned, the two functions may be required to reassess how the key terms "value proposition" and "lead may" be reconceptualized. These potential exigencies mandate that even after agreeing upon key terms at the outset, marketing and sales functions must maintain open and bidirectional communication channels so that the needed clarifications and redefinitions of key terms are obtained in a timely manner. Erin notes below:

Even though we have a plan in place, owing to the time it takes to win [hospital] accounts in our business, we are constantly revisiting, refining goals along the way. [In these markets] you are never going to hit bullseye the first time ... it is about constant evaluation and having feedback loops with sales active and alive, and incorporating those changes ... if that means changing our initial assumptions and key definitions, we do that (Erin, Pharmaceuticals, Chief Marketing Officer).

Based on the above discussion, I propose the following:

P1. Agreement between sales and marketing upon key terms has a positive effect on strengthening the interfunctional connection, provided firms (a) institute effective vertical communication mechanisms within each functional hierarchy to prevent the loss of key terms' meaning, and (b) build horizontal communication bridges between the two functions at various levels to facilitate contextual interpretation of key terms.

P2. Agreement between sales and marketing upon key terms has a positive effect on strengthening the interfunctional connection, provided firms have open and bidirectional inter-functional communication channels that allow for clarifications and redefinitions of key terms between sales and marketing over time as strategy unfolds.

\section{Structure}

Literature has stressed the benefits of creating a single demand generation process (Kotler et al., 2006; Oliva, 2006) through the use of decentralization, joint sales marketing activities, and coordination of sales and product management activities (Cespedes, 1996; Kotler et al., 2006; Rouziès et al., 2005). My data suggest that while the two functions may collectively come up with a single demand generation process, two boundary conditions affect whether this structural initiative forges stronger connections between sales and marketing.

The first condition is each function's flexibility in allowing the customization of certain processes; even if such customization represents deviation from an organizationwide accepted strategic process. The importance of this boundary condition is stressed by the fact that many times, lack of big accounts in some regions necessitates that the salesperson tweak the demand generation process for his /her territory. As Adam notes below, unless marketers exhibit such flexibility in allowing salespeople to tweak tactical elements of the strategy, certain strategies may fail thus negatively affecting sales-marketing connections:

The most important thing [about any strategic process] is being flexible, and being willing to try many different things. At least in our business, the most important thing is to say ... there are probably many different ways of successfully moving forward. We need to be flexible enough to say, we are going to try this ... and if it does not seem to be resonating in any region, then we are going to try something else there ... as opposed to keeping on beating a dead horse (Adam, Industrial Products, Regional Marketing Manager).

As Lisa's quote below indicates, being flexible requires both marketers and salespeople to be willing to engage in "give and take". Specifically, my data indicate that if one function asks the other to go an extra mile to insure strategic success, it should also be willing to accommodate the other function's requests. Specifically, Lisa highlights how she is flexible in moving to a premium price for her key customers in exchange for marketers' promise to be flexible in servicing such accounts:

I call it "give and take" ... I mean they [marketers] should be willing to give something to get something in return. I am open to negotiating with my marketing partners about the various pricing options for my key customers ... and even go with the premium pricing ... only if they guarantee that they will support me in servicing these accounts round the clock and not stick to their standard support procedures (Lisa, Sales Executive, IT).

The second boundary condition is organizational hierarchy. Research suggests that leaders play an important role in organizations by setting the tone for functional strategies (Kohli and Jaworski, 1990). My data indicate that if the jointly created demand generation processes do not have the "blessings" from either sales or marketing leadership, it sends mixed signals to the middle and lower-level executives: for example, if the VP of sales does not agree with the jointly devised action plan, he/she may send subtle signals within the sales organization to that effect. This may create dissonance between the two functions if marketing personnel find their sales counterparts to be unenthusiastic about the "jointly created" action plan. In addition, it is the middle and lower managers who implement the strategies. Hence, it is imperative that strategies have the blessings of not only the functional leadership, but also that individuals at each level within the sales and marketing functions take "ownership" of the strategic process. The following two quotes bring forth these notions clearly:

In this company, it starts at the top. Many times, the VP of sales may go into meetings with the sales directors and regional managers and trash all the things we do ... and it kinda flows down, it is a top down thing. Our CEO has a lot of work on his hands... these executives who are running sales and marketing organizations are out of sync ... and we are seeing all the backbiting taking place throughout the enterprise (Steve, Telecom, Senior Marketing Executive)

One of our major initiatives failed because our district managers and sales reps did not feel excited about it ... so field marketing kept beating the dead horse so that they would implement the program ... that did not happen but it created a strain between the two at my level (Lisa, Pharmaceuticals, Field Marketing Manager).

Based on the above discussion, I propose:

P3. Creation of a single organization-wide demand generation process has a positive effect on strengthening the sales-marketing connections, provided both marketers and sales personnel 
maintain flexibility in accommodating deviations from the proposed process during strategy implementation.

P4. Creation of a single organization-wide demand generation process has a positive effect on strengthening the sales-marketing connections, provided all levels within the sales and marketing hierarchy take ownership of that process.

\section{Process artifacts}

Scholars (Cespedes, 1996; Oliva, 2006) observe how it is crucial that firms clearly outline the artifacts of the demand generation process, such as having well-defined process charts and creating sub-teams that have a complete picture of the process from beginning to end. My data suggest that creation of joint sales-marketing teams can play vital role in insuring that sales organization has a say in the strategic processes, provided the work such teams perform get adequate visibility across the organization.

When salespeople are involved in strategy creation or strategy fine-tuning process; sales organization embraces new marketing initiatives easily, thereby reducing acrimony, and strengthening their connections with marketing. It is imperative, however, that marketers make the composition of such teams visible and highlight how the joint teams helped test -market various demand generation processes and improved process efficiencies.

As Nancy's quote highlights, her firm had great success with the joint teams after they started systematically highlighting who the joint team consisted of and how it worked. As she notes below, it was crucial that everyone knew how the team functioned and what processes it followed when coming up with new ideas and plans. Such information allowed sales organization to see the key role their representatives played in the entire process:

Forming the team is an important first step in the process ... it is equally important to spread the word about how the team is going to function and what role each member is going to play. To put it simply, our joint teams did well since we always offered sales organization some "proof" that their representatives had an important role to play in these teams and that they were not just "token representatives (Nancy, Sales Manager, Engineering).

My informants also emphasized that marketing and sales leadership must make concerted efforts to explore various avenues that can provide the needed visibility to joint teams. Specifically, they highlighted various channels such as company bulletin boards, intranet, e-mail blasts, sales meetings, or monthly telephone conferences between sales and marketing personnel through which firms may constantly showcase the joint teams and their work. Ronny noted:

It is important to maintain a high visibility for these joint teams because it reinforces to the sales force that we are in it together ... that both sales and marketing are fighting the same challenges and that they are trying to solve it with each other's help ... you never want your salespeople to lose sight of the fact that they are adequately represented in the strategic process (Ronny, Senior Marketing Manager, Telecom).

Based on the above discussion, I propose:

P5. Creation of joint sales-marketing teams has a positive effect on strengthening the sales-marketing connections, provided such teams and their work get visibility within the organization.
As noted earlier, my data helped me identify two additional linkages that have not been explored in the literature in greater detail till date. Below, I discuss these two linkages.

\section{Social linkages}

Homburg et al. (2008) identify "ivory tower" and "salesdriven symbiosis" as two new types of marketing-sales interfaces. Even though they do not make a direct reference to social linkages, their description of marketing's isolation in the ivory tower configuration (p.114), and the presence of extensive teamwork in the sales-driven symbiosis configuration (p. 146) suggests how important interpersonal and social linkages between the two functions can be. My data help unravel the nuances of these social linkages by identifying its two dimensions.

First, it suggests that the presence of social and relational bonds, both at the functional and individual levels, helps strengthen the sales-marketing linkage. For example, it helps if marketing and sales VPs at the top level of the organization as well as the field marketing manager and salesperson in the field share good personal relationship. Such a rapport facilitates the process of giving and receiving candid feedback and bringing the two functions onto the same page. The following two quotes indicate how strong personal relationships help bond these two functions:

When you [as a function] share a good rapport with sales group, you come together and think about how we can better our business. In this company, together, we try to understand how we can segment our customers better and build business. So having a good [functional] relationship has really made a difference for us because we get and give a very fair and candid feedback to sales group (Cheryl, Telecom, Field Marketing Manager).

Salespeople mention to me that of everyone in marketing, they have the best rapport with me. They tell me, I want your product to do well, because I like you. They almost buy into your mission (Vernon, Industrial Products, Regional Marketing Manager).

Second, my data suggest that the presence of informal social networks contributes to building social connections between sales and marketing. Specifically, I observed that many marketing (sales) managers cultivated an informal social network within the sales (marketing) organization in that they built personal relationships with various members of the sales (marketing) hierarchy. For example, a marketing manager would be friends with some regional sales managers, key account executives, and sales representatives. Such "informal network" gave managers quick access to critical (and informal) information and also strengthened the connections between the two functions:

I have a few salespeople who regularly call me for inside information [laughs] ... so if I need some feedback on my product ... instead of going to the sales manager, I ask Joe in LA and Steve in Louisiana. There are no filters ... I get news - good or bad - directly from the source ... of course, you have to build some degree of trust to get to that level (Dave, Engineering, HQ Marketing Support).

Based on the above discussion, I propose the following:

P6. Existence of social linkages between the sales and marketing personnel has a positive effect on the connections between the two functions. Personal rapport between sales and marketing professionals, and the presence of informal social networks between the two functions strengthen social linkages. 


\section{Philosophical linkages}

Tjosvold (1988) suggests that employees who believe that their goals are cooperative interact effectively and make progress on their tasks. In similar vein, scholars (Griffin and Hauser, 1996; Hutt, 1995; Sinkula et al., 1997) note that group goals and shared vision facilitate responsive and cooperative behaviors from managers in different organizational functions. In sales-marketing context, Kotler et al. (2006) propose that if revenue generation is made a joint responsibility for marketing and sales, it motivates them to integrate their thought worlds, market perspectives, and organizational structures. Overall, this body of work indicates that if different departments are committed to macro-level objectives, such commitment helps them to align their differences in orientations (short versus long-term, tactical versus strategic, or product versus customer orientation) and knowledge (product versus customer knowledge) in a productive way (Homburg and Jensen, 2007).

My informants noted that even though marketing and sales are "programmed for conflict by their design, roles, and responsibility", they can still find ways to surmount their differences if they are agreed on philosophical grounds. While most empirical and conceptual studies on sales-marketing interface are descriptive and have developed multidimensional models embodying language, structure, and process artifacts, they have largely ignored how this commitment to broader organizational philosophy may bring sales and marketing together. Below, I highlight some salient aspects related to the philosophical linkages between sales and marketing.

My informants noted that if marketing and sales personnel remained mindful of the various inherent differences between the two functions and made conscious efforts to accommodate these differences in order to achieve organizational objectives, it strengthened the connections between the two. Specifically, my data suggested that if both functions were committed to solving customers' problems, it motivated them to put customer needs above everything else. In such cases, their functional differences took a backseat and inter-functional connections were strengthened by their commitment to the common philosophy that customers came first:

The best way to remove the philosophical divide is instead of making it a formal marketing and a sales task, tie it together. In this company, we always keep in mind that we are here to solve customer's problem. Our own problems are secondary. When you believe in this core principle, you automatically iron out your differences and work together (Derek, IT, Senior Product Manager).

In similar vein, my data showed that when both functions allowed organizational goals to supersede their respective functional goals such as achieving quarterly sales or gaining market share, it helped create a sense of interdependence between the two functions. In such cases, marketing and sales personnel engaged in extensive cooperation since their success depended on how well they carried out joint activities in the marketplace. Once again, a commitment to a common philosophy - i.e. achieving organizational objectives - helped strengthen the connection between them. Ryan's quote below highlights the criticality of diffusing the goal differences early:

The difference is in philosophy where sales views the world as "I'm going to make this sale today whether it's a good one or not" and marketing's view that, "It's not a good long term sale and it probably flies in the face of our marketing direction". So you have to try and diffuse those things early on (Ryan, Telecom, Marketing Manager).

Last, it helped cement the philosophical linkage when sales and marketing functions looked at each other as being part of the same team. The belief that "we are in it together" helped each department appreciate the value added by the other department to their activities, and recognize the constraints under which they were operating. My data suggest that while it took time to build esprit de corps; when achieved, it helped firms overcome many challenges:

It is a big teamwork ... and I have always believed in the value of teamwork. In marketing and sales, you cannot achieve anything unless you have a good team. No marketing strategy can succeed on its own merit; it needs to be implemented accurately. Therefore, no function alone can claim that they are the reason things work out. You always have to let people know the importance of team and appreciate others' contributions. When you have that team spirit, it is a beautiful thing (Sandra, Telecom, Sales Manager).

Based on the above discussion, I propose:

P7. The existence of strong philosophical linkages between the sales and marketing personnel has a positive effect on the connections between the two functions. Such philosophical linkages may be forged if both functions (a) treat customers as their most important priority, (b) put organizational goals ahead of their functional goals, and (c) view the other function as partner.

\section{Discussion and theoretical contributions}

The existing literature on sales-marketing interface boasts of multidimensional models embodying language, structure, and process artifacts. By unraveling the contextual factors that may affect the role played by language, structure, and process dimensions in forging strong connections between sales and marketing, and identifying two new linkages that may bolster the connections between sales and marketing, this paper begins to explore the many nuances of how firms may bring sales and marketing closer. In particular, it identifies many subtleties that firms may need to pay attention to while trying to achieve marketing-sales integration. In doing so, this paper highlights the key role played by many organizational-level variables that have been investigated in different business disciplines, within the sales-marketing interface context and provides an initial trigger for greater research in this area. I discuss key contributions below.

First, while existing sales-marketing interface literature highlights how enhanced inter-functional communication (LeMeunier-FitzHugh and Piercy, 2007), as well as achieving alignment over definitions of key terms (Oliva, 2006) may help these two functions forge stronger connections; it is silent over boundary conditions that may affect this phenomenon. My findings highlight that the agreement between the senior sales and marketing executives on the meanings of key terms may not necessarily result in strong inter-functional linkages. Specifically, I highlight how it is crucial for firms to create and maintain vertical communication channels so that the meanings of key terms do not get lost as information flows down the sales and marketing hierarchy. Further, firms maintain open and bidirectional communication platforms at various levels, which may allow the managers the necessary flexibility to 
re-conceptualize their earlier definitions of key terms and arrive at their contextual interpretation should the need arise.

Extant research highlights the benefit of decentralization, use of teamwork (Cespedes, 1996; Piercy, 2006; Rouziès et al., 2005), and creation of a single demand generation process (Kotler et al., 2006; Oliva, 2006), in strengthening salesmarketing connections. The second contribution of this study is that it highlights the role played by two contextual conditions in this regard- marketing's flexibility and organizational hierarchy. Specifically, it suggests that during strategy implementation phase, both marketers and salespeople must exhibit flexibility and accommodate each other's requests for things such as tweaking strategies or providing additional support since it may go a long way in strengthening the connections between the two functions. Further, when all levels within the sales and marketing hierarchy take ownership of the demand generation process, it facilitates the process of sales-marketing integration.

The third contribution of this study lies in highlighting the need to offer greater visibility to the work done by the salesmarketing sub-teams (Oliva, 2006) that are involved in joint activities. The findings also highlight how it is important that sales and marketing managers make known the team composition and the roles played by sales and marketing personnel in such teams' activities, and constantly showcase the teams' achievements. While the extant literature highlights the use of cross-functional teams (Ingram, 2004), the role played by such teams' visibility in strengthening salesmarketing linkages has not been explored and constitutes a contribution of this study.

In addition to identifying the boundary conditions of the language, structure, and process linkages, the fourth contribution of this study lies in identifying two additional linkages, i.e. social and philosophical linkages. With respect to social linkages, I highlight how existence and nurturing of social linkages between individuals within these two functions may help strengthen the connection between sales and marketing. I further highlight how building personal rapport and creating a web of informal social networks with one's marketing (sales) counterparts may help build the social linkage. This finding thus builds on Homburg et al. (2008) study by offering the nuances of social linkages.

The last contribution of this study lies in identifying and unraveling the presence of philosophical linkages between sales and marketing, which have largely been ignored by the extant sales-marketing interface literature. Various studies on inter-departmental interfaces indicate that agreement over macro-level objectives allows various departments to align their differences in productive ways (Griffin and Hauser, 1996; Kotler et al., 2006; Tjsovold, 1988). While Strahle et al. (1996) find that goal differences may derail this interface, this study finds that when marketing and sales personnel agree in philosophy to make customer needs and organizational objectives their first priority, and appreciate that they are a part of the same team, it helps forge stronger connection between them. It thus suggests that philosophical linkages may help these two functions surmount their differences in orientations or knowledge (Homburg et al., 2008) and work constructively as a team.

\section{Limitations and future research}

This study has certain limitations. First, data for this study came only from participant interviews. Participant observation in informant firms may have provided deeper insights into these interface linkages. Second, my sample size of 47 could also be construed as relatively small, and a possible limitation. However, this size is typical of qualitative studies in business markets (e.g. Beverland et al. 2006). Also, I collected data until I reached theoretical saturation, which, at times, is reached after 20-30 interviews (Creswell, 2007, pp. 66-7). Third, given the exploratory nature of this research, generalizability of the study findings is another limitation. I tried to minimize this by selecting a diverse set of informants across industries. One might argue that I am theorizing about functional level dynamics using individual informant interviews. This is common, as scholars have studied organizational phenomenon using key informants (Tuli et al., 2007). Further, as noted earlier, I made every effort during interviews to stay focused on functional level. In addition, I did member checks at the end of the study. I believe that these measures helped me address the level of analysis issue. Last, this study investigates organizations with well-defined sales and marketing functions. I must note that a lot of firms in industries such as consulting services operate without a specialized sales function; for example in consultant businesses, it is top management who integrates sales and operations, while marketing is more or less reduced to a service-function.

As noted earlier, this study begins to explore the subtleties of forging strong connections within the sales-marketing interface. I treat this as an exploratory study and hence, the linkage repertoire I present here may not be treated as exhaustive. Future research may investigate nuances of the social and philosophical linkages I propose, as well as identify additional dynamic factors that may affect language, structure, and process linkages. Scholars may further our understanding of this phenomenon by identifying additional avenues/linkages between these two functions that may help forge stronger connections. Future research may also investigate how boundary conditions such as organizational culture, competitive intensity, or environmental uncertainty may moderate various linkages I have explored here. Testing the propositions presented here using quantitative data may also constitute future research opportunity.

\section{Managerial implications}

Managers may utilize the study findings in improving connections between the two functions. First, this study highlights the importance of maintaining vertical and horizontal communication bridges within and across both functions respectively. Sales and marketing managers may insure that they create and keep alive such formal and informal communication bridges within their organizations. They must also insure that these communication platforms provide opportunities for collective interpretation of ideas, meanings, and actions at various levels, in order to enhance organizational sensemaking (Gephardt, 1984; Thomas et al., 1993). These communication channels may also help organizational members in achieving clarifications and redefinitions of key terms based on market realities. 
The second takeaway for managers is that marketing must maintain flexibility in adapting their strategies in certain territories. Such adaptivenesss can help the regional sales force in achieving its business objectives. In addition, it may also send signals to the sales force about marketing's willingness to help them, thereby strengthening interfunctional connections.

Next, while many firms form joint sales-marketing task forces, it may not help if such task forces do not receive adequate visibility. This study highlights how managers need to not only give visibility to such teams but also communicate their successes and failures within the entire organization. Managers may use monthly or quarterly sales meetings or props such as marketing newsletters to display the work such teams have done. Managers may use such teams for constantly improving their work processes as well.

This study also shows that marketers may benefit if they build social connections with their sales counterparts, in addition to building language, process, and structural linkages. While I do not argue that social linkages can serve as a panacea for this interface, managers must understand that such relationships may help them when things are not going well. They may forge social connections through building personal rapport and informal networks.

Last, functional leadership may work toward building philosophical linkages between sales and marketing. Leaders must strive to create a shared vision that puts customer needs above everything else and makes sales and marketing personnel believe that customer pains are more important than the inter-functional troubles. Such leaders may also try to enhance sales and marketing's commitment to organizational goals and steer them away from thinking only about their functional goals. They may also work toward creating a team spirit between the two functions so that they view each other as partners and not obstacles in achieving their objectives.

\section{References}

Beverland, M., Steel, M. and Dapiran, G.P. (2006), "Cultural frames that drive sales and marketing apart: an exploratory study", fournal of Business E Industrial Marketing, Vol. 21, pp. 386-94.

Biemans, W., Makovec Brenčič, M. and Malshe, A. (2009), "Marketing-sales interface configurations in B2B firms", Industrial Marketing Management, Vol. 39, pp. 183-94.

Cespedes, F.V. (1993), "Coordinating sales and marketing in consumer goods firm", Fournal of Consumer Marketing, Vol. 10, pp. 37-55.

Cespedes, F.V. (1996), "Beyond teamwork: how the wise can synchronize", Marketing Management, Vol. 5, Spring, pp. 24-37.

Chimhanzi, J. (2004), "The impact of marketing/HR interactions on marketing strategy implementation", European fournal of Marketing, Vol. 38, pp. 73-98.

Colletti, J.A. and Chonko, L.B. (1997), "Change management initiatives: moving sales organizations from obsolescence to high performance", fournal of Personal Selling E Sales Management, Vol. 17, Spring, pp. 1-30.

Creswell, J. (2007), Qualitative Inquiry \& Research Design, 2nd ed., Sage Publications, Thousand Oaks, CA.
Crittenden, V.L., Gardiner, L.R. and Stam, A. (1993), "Reducing conflict between marketing and manufacturing", Industrial Marketing Management, Vol. 22 No. 11, pp. 299-309.

Dawes, P.L. and Massey, G.R. (2005), "Antecedents of conflict in marketing's cross-functional relationship with sales", European fournal of Marketing, Vol. 39, pp. 1327-44.

Dawes, P.L. and Massey, G.R. (2006), "A study of relationship effectiveness between marketing and sales managers in business markets", Fournal of Business E Industrial Marketing, Vol. 21, pp. 346-60.

Deshpandé, R. (1983), “Paradigms lost': on theory and method in research in marketing", fournal of Marketing, Vol. 47, Fall, pp. 101-10.

Dewsnap, B. and Jobber, D. (2000), “The sales-marketing interface in consumer packaged-goods companies: a conceptual framework", Fournal of Personal Selling $\mathcal{E}$ Sales Management, Vol. 20, Spring, pp. 109-19.

Dewsnap, B. and Jobber, D. (2002), “A social psychological model of relations between marketing and sales", European Fournal of Marketing, Vol. 36, pp. 874-94.

Gephardt, R.P Jr (1984), "Making sense of organizationally based environmental disasters", fournal of Management, Vol. 10 No. 2, pp. 205-25.

Glaser, B.G. and Strauss, A.L. (1967), The Discovery of Grounded Theory, Aldine Publishing, Chicago, IL.

Griffin, A. and Hauser, J.R. (1996), "Integrating R\&D and marketing: a review and analysis of the literature", fournal of Product Innovation Management, Vol. 13 No. 5, pp. 191-215.

Guenzi, P. and Troilo, G. (2006), "Developing marketing capabilities for customer value creation through marketingsales integration", Industrial Marketing Management, Vol. 35 No. 11, pp. 974-88.

Guenzi, P. and Troilo, G. (2007), “The joint contribution of marketing and sales to the creation of superior customer value", fournal of Business Research, Vol. 60 No. 2, pp. 98-107.

Gummesson, E. (2003), “All research is interpretive!", fournal of Business $\mathcal{E}$ Industrial Marketing, Vol. 18, pp. 482-92.

Homburg, C. and Jensen, O. (2007), "The thought worlds of marketing and sales: which differences make a difference?", Fournal of Marketing, Vol. 71, July, pp. 124-42.

Homburg, C., Jensen, O. and Krohmer, K. (2008), "Configurations of marketing and sales: a taxonomy", Fournal of Marketing, Vol. 72, March, pp. 133-54.

Hutt, M.D. (1995), "Cross-functional working relationships in marketing", fournal of the Academy of Marketing Science, Vol. 23, Fall, pp. 351-7.

Ingram, T.N. (2004), "Future themes in sales and sales management: complexity, collaboration, and accountability", Fournal of Marketing Theory E Practice, Vol. 12, Fall, pp. 18-28.

Kahn, K.B. and Mentzer, J.T. (1996), "Logistics and interdepartmental integration", International fournal of Physical Distribution E Logistics Management, Vol. 26, p. 6.

Kohli, A.K. and Jaworski, B.J. (1990), "Market orientation: the construct, research propositions, and managerial implications", fournal of Marketing, Vol. 54 No. 4, pp. 1-18. 
Kotler, P., Rackham, N. and Krishnaswamy, S. (2006), "Ending the war between sales and marketing", Harvard Business Review, Vol. 84, pp. 68-78.

LeMeunier-FitzHugh, K. and Piercy, N.F. (2007), "Does collaboration between sales and marketing affect business performance?", Fournal of Personal Selling \& Sales Management, Vol. 27, Summer, pp. 207-20.

Leenders, M.A.A.M. and Wierenga, B. (2002), "The effectiveness of different mechanisms for integrating marketing and R\&D", fournal of Product Innovation Management, Vol. 19 No. 7, pp. 305-17.

Lim, J.-S. and Reid, D.A. (1992), "Vital cross-functional linkages with marketing", Industrial Marketing Management, Vol. 21 No. 5, pp. 159-65.

Lincoln, Y.S. and Guba, E.G. (1985), Naturalistic Inquiry, Sage Publications, Beverly Hills, CA.

Lorge, S. (1999), "Marketers are from Mars, salespeople from Venus", Sales and Marketing Management, Vol. 151 No. 4, pp. 26-33.

Lucas, G.H. Jr and Bush, A.J. (1988), "The marketing-R\&D interface: do personality factors have an impact?", fournal of Product Innovation Management, Vol. 5 No. 12, pp. 257-68.

McCracken, G. (1988), The Long Interview, Sage Publications, Newbury Park, CA.

Malshe, A. (2009a), "How is marketers' credibility construed within the sales-marketing interface?", Fournal of Business Research, Vol. 63, pp. 13-19.

Malshe, A. (2009b), "Strategic sales organizations: transformation challenges and facilitators within the salesmarketing interface", fournal of Strategic Marketing, Vol. 17 Nos 3/4, pp. 271-89.

Malshe, A. and Sohi, R.S. (2009a), "Sales buy-in of marketing strategies: exploration of its nuances, antecedents and contextual conditions", Fournal of Personal Selling and Sales Management, Vol. XXIX No. 3, pp. 207-25.

Malshe, A. and Sohi, R.S. (2009b), "What makes strategy making across the sales-marketing interface more successful?", Fournal of the Academy of Marketing Science, Vol. 37 No. 4, pp. 400-21.

Maltz, E. (1996), "An enhanced framework for improving cooperation between marketing and other functions: the differential role of integrating mechanisms", fournal of Market Focused Management, Vol. 2, pp. 83-98.

Matthyssens, P. and Johnston, W.J. (2006), "Marketing and sales: optimization of a neglected relationship", fournal of Business \& Industrial Marketing, Vol. 21, pp. 338-45.

Matthyssens, P. and Vandenbempt, K. (2003), "Cognition-incontext: reorienting research in business market strategy", Fournal of Business $\mathcal{E}$ Industrial Marketing, Vol. 18 Nos 6/7, pp. 595-606.

Moenaert, R.K. and Souder, W.E. (1990), "An analysis of the use of extrafunctional information by $\mathrm{R} \& \mathrm{D}$ and marketing personnel: review and model", fournal of Product Innovation Management, Vol. 7 No. 9, pp. 213-29.
Morgan, N.A. and Piercy, N.F. (1998), "Interactions between marketing and quality at the SBU level: influences and outcomes", Fournal of the Academy of Marketing Science, Vol. 26, Summer, pp. 190-208.

Oliva, R.A. (2006), "The three key linkages: improving the connections between marketing and sales", fournal of Business E Industrial Marketing, Vol. 21, pp. 395-8.

Piercy, N.F. (2006), "The strategic sales organization", Marketing Review, Vol. 6, Spring, pp. 3-28.

Rouziès, D., Anderson, E., Kohli, A.K., Michales, R.E., Weitz, B.A. and Zoltners, A.A. (2005), "Sales and marketing integration: a proposed framework", fournal of Personal Selling \& Sales Management, Vol. 25, Spring, pp. 113-22.

Sherman, J.D., Souder, W.E. and Jenssen, S.A. (2000), "Differential effects of the primary forms of crossfunctional integration on product development cycle time", Fournal of Product Innovation Management, Vol. 17 No. 7, pp. 257-67.

Sinkula, J.M., Baker, W.E. and Noordewier, T. (1997), "A framework for market-based organizational learning: linking values, knowledge, and behavior", fournal of the Academy of Marketing Science, Vol. 25, Fall, pp. 305-18.

Song, X.M., Montoya-Weiss, M.M. and Schmidt, J.B. (1997), "The role of marketing in developing successful new products in South Korea and Taiwan", fournal of International Marketing, Vol. 5, p. 47.

Strahle, W.M., Spiro, R.L. and Acito, F. (1996), "Marketing and sales: strategic alignment and functional implementation", fournal of Personal Selling \& Sales Management, Vol. 16, Winter, pp. 1-20.

Strauss, A.L. and Corbin, J. (1998), Basics of Qualitative Research: Grounded Theory Procedures and Techniques, Sage Publications, Newbury Park, CA.

Thomas, J.B., Clark, S.M. and Gioia, D.A. (1993), "Strategic sensemaking and organizational performance: linkages among scanning, interpretation, actions and outcomes", Academy of Management fournal, Vol. 36 No. 2, pp. 239-70.

Tjosvold, D. (1988), "Cooperative and competitive interdependence”, Group and Organization Studies, Vol. 9, pp. 274-89.

Tuli, K.R., Kohli, A.K. and Bharadwaj, S.G. (2007), "Rethinking customer solutions: from product bundles to relational processes", fournal of Marketing, Vol. 71 No. 7, pp. 1-17.

Webster, F.E. and Montgomery, D.B. (1997), “Marketing's interfunctional interfaces: The MSI Workshop on Management of Corporate Fault Zones", fournal of Market Focused Management, Vol. 2 No. 1, pp. 7-26.

Weick, K.E. (2007), "The generative properties of richness", Academy of Management Fournal, Vol. 50 No. 1, pp. 14-19. Weinrauch, J.D. and Anderson, R. (1982), "Conflicts between engineering and marketing units", Industrial Marketing Management, Vol. 11, pp. 291-301. 


\section{Appendix}

Table Al In vivo codes, first-order categories, and second-order themes

\begin{tabular}{|c|c|c|}
\hline In vivo codes & First-order categories & Second-order themes \\
\hline \multicolumn{3}{|l|}{ Different perspectives } \\
\hline $\begin{array}{l}\text { Different understanding of the situation depending on where } \\
\text { you are in the hierarchy }\end{array}$ & $\begin{array}{l}\text { Levels within sales and marketing } \\
\text { Organizational pyramid }\end{array}$ & Organizational hierarchy \\
\hline \multicolumn{3}{|l|}{ Time to implement } \\
\hline $\begin{array}{l}\text { Long gestation periods } \\
\text { Lengthy processes }\end{array}$ & Long-term approach & $\begin{array}{l}\text { Long-term nature of strategy } \\
\text { creation and execution }\end{array}$ \\
\hline \multicolumn{3}{|l|}{ Process changes } \\
\hline Tweaking the demand generation process & Deviation & Function's flexibility \\
\hline Trying something new & Accommodation & \\
\hline \multicolumn{3}{|l|}{ Show progress } \\
\hline Communicate achievements & Team visibility & Team visibility \\
\hline \multicolumn{3}{|l|}{ Make the team composition known } \\
\hline \multicolumn{3}{|l|}{ Explore various channels to share team achievements } \\
\hline \multicolumn{3}{|l|}{ Individual bonds } \\
\hline Functional bonds & Personal rapport & Social linkages \\
\hline Relationships at individual and functional levels & Personal relationships & \\
\hline Friendships cutting across functional lines & Informal social groups & \\
\hline \multicolumn{3}{|l|}{ Agreement on philosophical grounds } \\
\hline Common customer-oriented philosophy & Commitment to broader organizational & Philosophical linkages \\
\hline Convergence of viewpoints & philosophy & \\
\hline \multicolumn{3}{|l|}{ Shared belief } \\
\hline Organizational goals greater than functional goals & & \\
\hline
\end{tabular}

\section{About the author}

Avinash Malshe (PhD, University of Nebraska-Lincoln) is Assistant Professor of Marketing, Opus College of Business, University of St Thomas, Minnesota, USA. His current research interest includes sales-marketing interface and its contribution to marketing strategy. His work has been published or accepted for publication in fournal of the Academy of Marketing Science, Fournal of Business Research, European Fournal of Marketing, Industrial Marketing Management, Fournal of Personal Selling and Sales Management, Fournal of Strategic Marketing, Fournal of Business to Business Marketing, International Business Review, and International Small Business fournal. He has also coauthored a book chapter in a marketing thought piece titled "The service dominant logic of marketing". Avinash Malshe can be contacted at: amalshe@stthomas.edu

\section{Executive summary and implications for managers and executives}

This summary has been provided to allow managers and executives a rapid appreciation of the content of the article. Those with a particular interest in the topic covered may then read the article in toto to take advantage of the more comprehensive description of the research undertaken and its results to get the full benefit of the material present.

Your company has good products or services and a wellthought-out strategy of achieving its aims. It also has a sales force which heads in one direction and a marketing team which goes off in another. Sound familiar? Sadly, it's all too common to have the sales and marketing operations acting as if they're competitors, not colleagues. Crazy, but it's true. All too often these two important groups appear to have different goals, different perspectives, physical separation and poor communication and coordination. In short, they don't get on.

Taken together, marketing and sales functions play a critical role in ensuring that firms deliver the desired customer value and it goes without saying that an effective sales-marketing interface is an important determinant of how well the firm creates, delivers and communicates its value proposition.

When sales and marketing departments are able to forge strong connections, firms benefit and positive outcomes ensue, such as greater customer value, overall business performance, enhanced departmental and product management performance and enhanced learning capabilities. Obstacles to achieving this desirable state of affairs include interfunctional conflicts, differences in goal 
orientation, tension regarding standardization and adaption and turf and interpretive barriers

By taking a close look at sales and marketing professionals across different organizations in diverse industries, Avinash Malshe asks: (a) Are there (yet) unexplored contextual conditions that may affect how the frequently-noted linkage dimensions (language, process, and structure) may forge strong connections between sales and marketing? (b) Are there additional linkages that the sales and marketing functions may focus on to strengthen the connection between them?

He identifies the many nuances of how firms may bring sales and marketing closer. In particular the many subtleties that firms may need to pay attention to while trying to achieve marketing-sales integration. In doing so, he highlights the key role played by many organizational-level variables.

The study emphasizes the importance of maintaining vertical and horizontal communication bridges within and across both functions respectively. Sales and marketing managers may ensure that they create and keep alive such formal and informal communication bridges within their organizations. They must also ensure that these communication platforms provide opportunities for collective interpretation of ideas, meanings, and actions at various levels, in order to enhance organizational sensemaking. These communication channels may also help organizational members in achieving clarifications and redefinitions of key terms based on market realities.

Marketing must maintain flexibility in adapting their strategies in certain territories. Such adaptivenesss can help the regional sales force in achieving its business objectives. In addition, it may also send signals to the sales force about marketing's willingness to help them, thereby strengthening interfunctional connections.

While many firms form joint sales-marketing task forces, it may not help if such task forces do not receive adequate visibility. Managers need to not only give visibility to such teams but also communicate their successes and failures within the entire organization. They may use monthly or quarterly sales meetings or props such as marketing newsletters to display the work such teams have done. They may also use such teams for constantly improving their work processes.

Marketers may also benefit if they build social connections with their sales counterparts, in addition to building language, process, and structural linkages. The author does not argue that social linkages can serve as a panacea for this interface, but says managers must understand that such relationships may help them when things are not going well. They may forge social connections through building personal rapport and informal networks.

Functional leadership may work toward building philosophical linkages between sales and marketing. Leaders must strive to create a shared vision that puts customer needs above everything else. Such leaders may also try to enhance sales and marketing's commitment to organizational goals and steer them away from thinking only about their functional goals. They may also work toward creating a team spirit between the two functions so that they view each other as partners and not obstacles in achieving their objectives.

During strategy implementation, both marketers and salespeople must exhibit flexibility and accommodate each other's requests for things such as tweaking strategies or providing additional support since it may go a long way in strengthening the connections between the two functions. Further, when all levels within the sales and marketing hierarchy take ownership of the demand generation process, it facilitates the process of sales-marketing integration.

The study highlights the need to offer greater visibility to the work done by the sales-marketing sub-teams that are involved in joint activities. It also stresses how important it is that sales and marketing managers make known the team composition and the roles played by sales and marketing personnel in such teams' activities, and constantly showcase the team's achievements.

( $A$ précis of the article "An exploration of key connections within sales-marketing interface". Supplied by Marketing Consultants for Emerald.)

To purchase reprints of this article please e-mail: reprints@emeraldinsight.com Or visit our web site for further details: www.emeraldinsight.com/reprints 